Kazimierz Sikora

Uniwersytet Jagielloński, Kraków

jolka_kazikowa@poczta.fm

\title{
ŻYCZENIA I WINSZOWANIE JAKO AKT MOWY
}

Słowa klucze: pragmatyka językowa, akty mowy, etykieta językowa, etnolingwistyka, lingwistyka antropologiczna

Keywords: linguistic pragmatics, speech acts, linguistic etiquette, ethnolinguistics, anthropological linguistics

Życzenia i składanie życzeń można rozumieć jako formę językowego działania w interakcji - na równi z podziękowaniem, prośbą, radą, zaproszeniem itp. Z takim stanowiskiem zgodziłby się zapewne twórca teorii aktów mowy John Austin, tym bardziej że mają one swój czasownik performatywny, wykładający intencję mówiącego: $\dot{z} y c z e ̨ /$ $\dot{z} y c z y m y$ i winszuję/winszujemy. Także na gruncie współczesnej lingwistyki pogląd ten nie budzi kontrowersji, por. takież rozumienie ang. wish: I wish you well, czy niem. wünschen: Ich wünsche Ihnen alles Gute. Życzenia należą do podstawowego repertuaru form grzecznościowych, głównie ze względów emocjonalnych: nie darmo kojarzą się z życzliwością, radością ze spotkania, serdecznością i pragnieniem dobra dla kogoś ${ }^{1}$. Życzenia wysoko sytuują się w opisach polskiej i europejskiej grzeczności językowej, np. Małgorzaty Marcjanik (1997, 2007) i Kazimierza Ożoga (1990, 2005), Geoffreya Leecha (1983), Silvii Bonacchi (2011). Powiedzielibyśmy, może nieco górnolotnie - że życzenie komuś czegoś dobrego jest odpowiedzią na pragnienia i oczekiwania drugiego

1 Sens życzeń, mało oczywisty na poziomie konkretnych zachowań grzecznościowych, daje się zamknąć w ogólnej formule eksplikacji: 'Mówię, że chcę dla ciebie dobra (X)', por. Marcjanik 1997: 64. 
człowieka, których sami jesteśmy lustrzanym odbiciem. Co z serca idzie, to do serca trafi - przekonuje przysłowie. Bogata tradycja życzeń jest kultywowana i rozkwita wręcz na gruncie towarzyskim. Potrzeby polskiej kultury pod tym względem mogą zaskoczyć badacza: choćby liczbą i zasobnością stron internetowych ${ }^{2}$ oferujących teksty życzeń na każdą niemal okazję. Także na walentynki i Halloween.

Tezy, że treść życzeń jest w znacznym stopniu zdeterminowana kulturowo, a jednocześnie jest warunkowana indywidualną zdolnością do empatii, rozpoznaniem pozycji i roli społecznej rozmówcy, można dowodzić na wiele sposobów. Dziecku życzymy sukcesów w nauce, rodzicom - pociechy z dzieci, ciężarnej - szczęśliwej godziny, szefowi firmy - pomyślności w interesach; inaczej winszujemy księdzu, inaczej rolnikowi, więźniowi itp. W każdej niemal sytuacji możemy życzyć zdrowia, szczęścia i powodzenia, bowiem ich pozycja na giełdzie pożądanych stanów rzeczy i przedmiotów jest chyba niczym niezagrożona. Popyt na nie jest wieczny - i w mieście, i na wsi, gdzie żywa obecność dobrego słowa dla drugiego człowieka jest w językowej etykiecie bardziej widoczna (por. Sikora 2011).

Czego życzymy innym? Odpowiedź sięga poziomu trywialności: dobra, którego pragnęlibyśmy dla siebie. Jego ramy jednak wyznacza kultura; zamykając przedmiot życzenia w kręgu społecznie aprobowanych oczekiwań, czyni z niego projekcję wyobrażeń osobistego i rodzinnego szczęścia, miłości, spełnienia, dobrego życia, zbawienia itp. Naruszenie ogólnie aprobowanego systemu wartości czyni z życzeń karykaturę i ogniskuje negatywne emocje. Politykowi nie wypada więc życzyć śmierci jego politycznych przeciwników, właścicielowi ośrodka leczenia z uzależnień - jak największej liczby pacjentów; szefowi firmy deratyzacyjnej - plagi szczurów, a strażakowi - seryjnego podpalacza w okolicy. Niekiedy zawodzi przekaz kulturowo-pokoleniowy (w sensie transmisji pewnych wartości) i ujawniają się różnice na poziomie wyobrażeń i oczekiwań. Taka publiczna kontestacja $\mathrm{z}$ reguły nosi znamiona prowokacji i skandalu obyczajowego. Warto w tym miejscu przypomnieć o niefortunnych życzeniach, skierowanych do Polaków przez piosenkarkę Agnieszkę Chylińską w milenijną noc sylwestrową ${ }^{3}$.

Dla porządku dodajmy, że przez chęć sprowadzenia na kogoś (rzadziej na coś) zła i nieszczęścia życzeniom przeciwstawiają się złorzeczenia („złe życzenia”). W przypływie silnych negatywnych emocji, mających swoją przyczynę w adresacie, mówiący

2 Badacz bez trudu odkryje, że jest ich (w polskim wydaniu) około dziesięciu. Nie wymienia się ich tutaj, by nie robić reklamy tym wątpliwej wartości dokonaniom, nazbyt często naruszającym zarówno prawa autorskie, jak i dobre obyczaje.

3 Popularna piosenkarka w noc sylwestrową 2000 r. w programie telewizyjnym złożyła widzom bardzo kontrowersyjne noworoczne życzenia będące kwintesencją tzw. luźnego mówienia, co sama skomentowała w wywiadzie prasowym następująco:

W sylwestra nikogo nie obraziłam i nikogo nie będę przepraszać. Nie wyzywałam nikogo od ch..., nie mówiłam na przykład, żeby wypier... Po prostu weszłam na scenę. Złożyłam życzenia. Powiedziałam: k... mać. Zajebiście, że się widzimy. Życzę wam wykurwistego Nowego Roku. Kolega dorzucił, żeby ludzie dobrze się ruchali, czyli kochali, i nachlali. Czyli, żeby w tym Nowym Roku ludziom nie zabrakło tego, co i ja lubię najbardziej - dobrego seksu i dobrego drinka... (Super Express, 9 I 2001). 
kieruje na niego swoje działanie werbalne o charakterze magicznym, np. żeby ich pokręciło, niech go szlag trafi, obyśzdechła, franco jedna itp. (por. np. Przybylska 2010: 299; 1986; Engelking 1991a, 1991b, 2010; Wierzbicka 1986, 1999). Z zasobu polskich prac naukowych poświęconych życzeniom i winszowaniu zdaje ogólnie sprawę dołączony do niniejszego artykułu wykaz literatury (głównie prac z nurtu lingwistyki antropologicznej i kulturowej, etnolingwistyki, antropologii kultury, folklorystyki oraz lingwistyki tekstu i stylistyki); z braku miejsca nie będzie się ich omawiać, poprzestając na nawiązaniach $w$ tekście ${ }^{4}$.

Jako akt mowy życzenie (winszowanie) wymaga w swoich warunkach fortunności:

a) Przekonania mówiącego, że dany stan rzeczy jest korzystny dla odbiorcy (warunek korzyści jest więc pod tym względem zaprzeczeniem groźby, złorzeczenia, przekleństwa) i nie nastąpi samoistnie.

b) Dla mówiącego wiąże się to ponadto z oczekiwaniem, że taka pozytywna zmiana nie miała miejsca już wcześniej albo że taką samą wartość może mieć dla odbiorcy trwanie czegoś, wcale nieoczywiste w świetle życiowej wiedzy (np. zdrowie, powodzenie, szczęście itp.).

c) Najbardziej kłopotliwą kwestią w interpretacji życzeń jako aktów dyrektywnych pozostaje warunek wstępny, obejmujący możliwość realizacji komunikowanych treści. Jak się wydaje, nie ma istotnych podstaw, by dowodzić bezpośredniej kontynuacji myślenia magicznego we współczesnym zwyczaju składania życzeń (podobnie jak w modlitwie, zbieraniu na tacę w kościele, błogosławieństwie rodzicielskim przed wyjściem państwa młodych do kościoła, czynieniu im znaku krzyża na czole, w obrzucaniu ich po wyjściu z kościoła ryżem lub drobnymi monetami, trącaniu się kieliszkami albo w dopingowaniu na stadionie, pokazywaniu komuś odgiętego w górę kciuka, dawaniu kopniaka na szczęście, śpiewaniu frywolnych piosenek podczas wesela itp.). W świetle faktów językowych najważniejsze jest, że nadawca chce $^{5}$, aby odbiorca doświadczył jakiegoś dobra, a także to, że obaj przynajmniej

4 Warto jednak podkreślić w tym miejscu szczególną, inspirującą rolę prac Anny Wierzbickiej, Anny Engelking, a przede wszystkim Piotra Kowalskiego, które znacząco zmieniły poglądy autora na rolę życzliwego, zjednującego dobro słowa w kulturze i etykiecie. W interdyscyplinarnych w istocie pracach P. Kowalskiego i A. Engelking znaleźć można licznie zestawioną nowszą literaturę dotyczącą interesującego nas zagadnienia.

5 Wiele miejsca poświęca temu tematowi w swoim imponującym studium P. Kowalski (2010). Kwestia szczerości i prawdziwości intencji nadawcy oraz wartości życzenia podlega obyczajowej regulacji i pozostaje pod presją konwenansu, niejako normalizując także ten element znaczenia (presupozycyjnie) formuł życzących. W ten sposób oczekiwanie dobrych intencji splata się z oczekiwaniem realności życzenia. Jeśli pominiemy te zależności, dostrzegalne tylko w niektórych, ekspresywnych formułach życzeń, należy stwierdzić, że z punktu widzenia językowej etykiety kwestia szczerości intencji nadawcy schodzi na plan dalszy i zostaje zawieszona, staje się nierelewantna przez wzgląd na funkcję pragmatyczną, bowiem o skuteczności aktów językowej grzeczności decyduje zgodność z wymogami społecznej konwencji, stosowność obyczajowa, a nie ich treść (Do widzenia! = 'mówię ci, że kończę kontakt $\mathrm{z}$ tobą). Znajduje to wyraz praktyczny w stosowanych przez badaczy (np. cytowaną 
dopuszczają możliwość jego realizacji, leżącą jednak poza ich władzą. Tak na przykład, jak głównej wygranej w totolotka po trzeciej kumulacji. Jeśli nawet utraciliśmy wiarę w sprawczą moc słowa i nie poczuwamy się do bliskiego powinowactwa $z$ „człowiekiem prymitywnym”, który hołduje rytuałom i zwyczajom o proweniencji magicznej (por. Kowalski 2010), to zgodzić się musimy, że życzenia realizują program minimalny: sprawiają przyjemność odbiorcy - beneficjentowi tego dobra, wyróżniają go w relacji interpersonalnej (Marcjanik 1997: 63-64).

Jednak nawet ograniczając efekt illokucyjny do tworzenia dobrego nastawienia odbiorcy, nie unikniemy dalszych pytań, związanych choćby z konwencjonalizacją i rytualizacją tekstów życzeń. Anna Wierzbicka (1986), eksplikując znaczenie aktów przekleństwa, błogosławieństwa i komplementu w kulturze żydowskiej, sformułowała ten składnik ze strony nadawcy ogólnie jako: 'wyobrażam sobie, że mówiąc to, mogę spowodować, że to się stanie’. M. Marcjanik (1997: 64), nawiązując do refleksji A. Wierzbickiej nad znaczeniem ang. to wish (1987), eksplikuje tę treść następująco: 'mówiąc, że życzę ci X, mówię, że wiem, że jeśli to wypowiem, to być może tak się stanie'.

Nie wyklucza to, rzecz jasna, że takie przeświadczenie może mieć podstawy religijne lub (w przekonaniu nadawcy) w inny sposób zależeć od sfery transcendencji i sił nadprzyrodzonych. A. Engelking w swej Klatwie. Rzeczy o ludowej magii słowa (2010) eksponuje dyrektywno-sprawczy wymiar życzeniowych aktów mowy w dawnej, tradycyjnej kulturze wiejskiej, z jej religijno-magicznym światopoglądem i wiarą w stwarzającą moc słowa. Traktować je można jako ukryte dyrektywy, których właściwym adresatem jest siła sprawcza, niebędąca człowiekiem. Tę transgresywną moc można zobligować siłą użytych formuł do spełnienia treści życzenia, prośby, nakazu, klątwy, egzorcyzmu itp. Mamy więc do czynienia ze złożoną strukturą dyrektywno-sprawczą $\mathrm{z}$ beneficjentem i factorem (benefactorem) w roli gwaranta i sprawcy oczekiwanej zmiany $^{6}$. Autorka przywołuje też stworzoną przez Annę Chudzik (2002: 56 i n.) eksplikację tego podstawowego sensu magicznego mówienia: 'mówiąc to, chcę, by cośsię stało i jestem pewien, że tak się stanie’.

Książka A. Chudzik pokazuje, jak wiele nadal elementów codziennego języka i obyczaju naznaczonych jest tą własnością, z czego do końca nie zdajemy sobie sprawy (por. też Kowalski 2010). Wieś współczesna pod tym względem zasadniczo nie różni się niczym od miasta.

M. Marcjanik 1997) formułach eksplikacyjnych, w pozycji nadrzędnego predykatu stawiających "mówię, że...” - reprezentujące sens językowego działania zgodnie z wymogami etykiety.

6 W sposób przekonywający dowodzą tego także argumenty historycznojęzykowe. Por. np. dobrze znane wśród życzeń o treści religijnej pozdrowienie przy pracy: Szczęść Boże!; podziękowanie: Bóg zapłać (komuś) 'niech Bóg wynagrodzi...'; Dobranoc! $\leq{ }^{\star}$ Bóg daj dobrą noc! (por. Krawczyk-Tyrpa 1997). O etymologii podstawowych operatorów trybu życzącego, np. niech i niechaj, oby zob. niżej. 
d) Na koniec przeglądu warunków skuteczności aktu składania życzeń należy wymienić komponent pozytywnego wartościowania. Obejmuje on zarówno opisywany stan rzeczy, jak też jakość wyrażanej emocji ukierunkowanej na odbiorcę oraz istnienie ograniczeń relacji interpersonalnej (częstszą niesymetryczność) pomiędzy uczestnikami takiego działania językowego: beneficjent życzeń jest dowartościowany kulturowo, co podkreślają różnorodne zachowania i gesty (por. Marcjanik 1997: 63 i n.).

Aleksy Awdiejew w swojej Gramatyce interakcji werbalnej wzbrania się przed włączeniem życzeń (choć ich przynależność do dyrektywnych aktów mowy nie budzi wątpliwości, tak samo jak wola nadawcy, by odbiorca doznał danego dobra) do aktów realizujących podstawowe interakcyjne strategie: informacyjno-weryfikacyjne i behawioralne - nakłaniające odbiorcę do jakiegoś działania lub do przyjęcia wobec proponowanego działania stanowiska zgodnego z oczekiwaniami nadawcy (2007: 72). Nie znajduje też dla życzenia-winszowania miejsca wśród aktów emotywno-oceniających (mimo pewnego ich podobieństwa do gratulacji i komplementów). W gruncie rzeczy istnieje też dość znaczące pokrewieństwo pomiędzy życzeniami a obietnicami, skoro to nadawca w tym stwarzającym stan zobowiązania akcie mowy postawiony jest $w$ roli wykonawcy, gwaranta i siły sprawczej deklarowanego działania (lub jego zaniechania) - z korzyścią po stronie odbiorcy. Autor ostatecznie włącza je do kategorii aktów mieszanych, modalno-emotywnych (wyrażanie obawy, nadziei, życzenia, chęci, wiary itp.). Na przykład akty nadziei zamykałyby się w pewności-przypuszczeniu, wspartym pozytywną emocją typu „wszystko będzie dobrze”, obawie zaś na odwrót podważonym emocją negatywną (Awdiejew 1987: 153-154). Z kolei chęć i życzenie łączyłyby trzy funkcje pragmatyczne: modalnego przypuszczenia, gotowości działania (dążenia do realizacji obranego celu) i pozytywnego stosunku emocjonalnego do pożądanego stanu rzeczy.

Proponowane rozwiązanie budzi jednak pewne zastrzeżenia. Głównie dlatego, że autor nie dość wyraźnie przeciwstawił życzenie „sobie” i życzenie komuś (winszowanie). Należałoby w moim przekonaniu postulować odrębne potraktowanie sytuacji, kiedy realizacja stanu rzeczy wyrażonego w propozycji stanowi korzyść dla odbiorcy, budzi pozytywne emocje, ale też nie jest zależna od kogokolwiek (2007: 155).

Według A. Awdiejewa złamanie warunku pozostawania w zasięgu realnych możliwości w obu przypadkach życzenia redukuje wartość komunikatu do sygnalizowania pewnego nastawienia emocjonalno-wartościującego zorientowanego pragmatycznie na rozmówcę. Nie popełniając chyba większego nadużycia, możemy to utożsamić z działaniem grzecznościowym (należącym do strategii grzeczności pozytywnej), polegającym na przekazaniu odbiorcy swoich przyjaznych uczuć, wyrażeniu empatii i życzliwego zainteresowania jego osobą (por. też Marcjanik 1997).

Z podobnym stanowiskiem, zamykającym sens składania życzeń w wymiarze etykietalnym - aktu służącego samej komunikacji, a nie osiągnięciu czegoś więcej niż (ważne 
z punktu widzenia korzyści nadawcy) zadowolenie czy potwierdzenie własnego statusu społecznego przez odbiorcę - można się spotkać w wielu opracowaniach. Na przykład François Récanati (1987: 110), nawiązując do poglądów Oswalda Ducrota, wyraża przekonanie, że przykładowo w tak silnie skonwencjonalizowanym życzeniu szybkiego powrotu do zdrowia chodzi o zakomunikowanie odbiorcy takiego oczekiwania (nadziei) nadawcy ('chcę, żebyś wiedział, że mam nadzieję, że...'), nie zaś o akt sprawczy typu: 'chcę, żebyś wyzdrowiał'. Przejście od czynności należących do porządku magicznego tradycyjnej kultury typu ludowego do ich przekształcenia do postaci aprobowanej w kulturze symbolicznej w interesujący sposób śledzi P. Kowalski. On także jest zdania, że skuteczność życzeń sprowadza się do skuteczności i produktywności konwenansu; jako spełnienie zobowiązań towarzyskich zamyka się w retorycznym efekcie $\mathrm{i}$ „udatności we wpisywaniu się nadawcy w zobowiązania konwenansu" (2010: 92). Świadczy o tym według niego wątpliwa etycznie wartość pustych semantycznie, stereotypowych, zbanalizowanych form okazywania szacunku i pamięci lub zainteresowania wobec drugiej osoby - należących do podstawowych reguł polskiej grzeczności. Trawestując zdanie autora: nie semantyka więc, lecz pragmatyka daje narzędzia interpretacji realnego znaczenia życzących aktów mowy (2010: 113). Tym bardziej że życzenia należą do konwencjonalnej gry społecznej, w której zachowują wartość daru wymagającego odwzajemnienia, choćby w formie podziękowania za nie darczyńcy. Najbardziej przejrzyście relacja ta rysuje się w formach obrzędowego kolędowania i wszelkich oracji życzących wygłaszanych przy tej okazji (por. Niebrzegowska-Bartmińska 2007). Bez większego trudu można się jej dopatrzyć również w reaktywnych zwrotach i formułach pozdrowień, domagających się dziękczynnej odpowiedzi, por. np. należące do wiejskiej etykiety: Szczęść Boże! - Daj Panie Boże! - Boże pomagaj! - Boże prowadź! - i innych. W znacznej części konwencjonalne życzenia utraciły już prymarną wartość illokucyjną i stały się wykładnikami werbalnych aktów grzecznościowych, służących w komunikacji interpersonalnej zwłaszcza nawiązywaniu, podtrzymywaniu lub kończeniu kontaktu (funkcja fatyczna), utrwalaniu poczucia więzi społecznej łączącej rozmówców, por. dzień dobry!, smacznego! itp.

Zamykając ten wątek rozważań, uznać należy ogólną słuszność przedstawionych wyżej stanowisk i racji. Jednak, jak już to ująłem w innym miejscu (Sikora 2011: 178):

[...] rozstrzygnięcie takie zamyka procedury weryfikujące w swoistej pułapce racjonalności i w ostatecznym rezultacie każe wszelkie życzenia traktować jako rodzaj językowej gry w poprawianie sobie i innym samopoczucia, kreowanie dobrej atmosfery w kontaktach interpersonalnych, demonstrowanie życzliwości przewidziane w regułach odnoszenia się do innych.

Takiemu ujęciu można wytknąć negatywnie ciążący nad opisem związek z obcym dzisiejszej racjonalności elementem magii i zabobonów. Ale także odsuwanie problemu pozytywnej postawy nadawcy i szlachetności jego intencji, której nie pozwala zweryfikować sam stopień konwencjonalizacji i rytualizacji ich językowych wykładników. Przedmiotem zbytniego uogólnienia jest (pomijany często ze względów 
pozanaukowych) aspekt religijny aktów życzeń, w jakiś sposób ciągle obecny zarówno w językowym kształcie formuł (Niech Wam Matka Boska błogosławi na nowej drodze życia!), jak również w świadomości zbiorowej ${ }^{7}$. Można także w sposób uzasadniony odwołać się do reliktów i enklaw magicznego myślenia i folkloru, dających liczne i uporczywe refleksy trudne do jednoznacznej oceny (chiromancja, horoskopy, ezoteryczne programy telewizyjne, popularność przepowiedni, wróżbiarstwa i znachorstwa).

Uznanie, że życzenia spełniają podstawowo wymogi konwenansu, czyni z nich akty prymarnie performatywne (w tradycyjnej klasyfikacji Johna Austina życzenia to behabitywy - akty wyrażania postawy wobec innych i ich spraw; należą tu między innymi pokrewne życzeniom błogosławieństwa i przekleństwa) o funkcji kreowania właściwej społecznie atmosfery w stosunkach interpersonalnych („atmosfery grzecznościowej”), dokonania przewidzianej w tym celu czynności słownej (por. Tomiczek 1992; Habrajska 1993: 384). W ogólnie znanej klasyfikacji Johna Searle’a interesujące nas akty mowy zostały włączone do ekspresywów, bowiem już nie uderzający stopień ich językowej konwencjonalizacji, lecz samo wyrażanie stanów emocjonalnych i psychicznych nadawcy przyjęto jako ich cechę wyróżniającą (stąd współobecność kondolencji, gratulacji, życzeń, błogosławieństw itp.). Dodajmy, że respektowanie choćby w niewielkim stopniu obecności funkcji sprawczej w formułach życzeń, błogosławieństw, pociągałoby za sobą konieczność uznania w nich reprezentantów kategorii przejściowej, mającej nadto cechy deklaratywów. Do tych z kolei niewątpliwie należą ludowe rytuały słowne (np. klątwa, zażegnywanie itp.), ale przecież i życzenia wigilijne, kolędy życzące i tradycyjne oracje winszujące, które dawniejsi odbiorcy rozumieli nie w sposób współczesny, lecz jako wypełnienie treści obrzędowej. Po dziś dzień w starszym pokoleniu (nie tylko na wsi) żywe pozostaje poczucie odpowiedzialności za słowo związane z sacrum, z systemem symboli rytualnych, które odgrywają rolę interpretanta (nie pragmatyczne warunki kontekstu) takich formuł werbalnych.

Wśród operatorów funkcji życzącej obok podstawowych czasowników performatywnych (życzę/życzymy, winszuję/winszujemy) występują także inne jednostki leksykalne. Komunikowanie życzenia, oczekiwania i woli jest w polszczyźnie związane z występowaniem na poziomie zdania specyficznych wyrazów funkcyjnych, w literaturze naukowej nazywanych często partykułami życzacymi, partykułami optatywnymi, analitycznymi wykładnikami trybu życzacego. Podkreśla się w związku z polifunkcyjnością gramatyczną tych leksemów (chodzi głównie o homonimy spójnikowe), że wartość tę, pierwotną funkcję woluntatywną i optatywną (komunikowanie życzenia, pragnienia, oczekiwania, woli w przekonaniu mówiącego możliwych do realizacji w przyszłości lub teraz) zachowują zdania samodzielne, niezwiązane stosunkiem hipotaktycznym.

7 Jako związaną z tym ciekawostkę podam, że powszechnie funkcjonuje na wsi przekonanie, że zbyt wylewne okazywanie komuś wdzięczności za dobre słowo i gest pomocy nie jest pożądane. Choć pozostaje to $\mathrm{w}$ niejakim konflikcie z powszechnie stosowaną $\mathrm{w}$ kulturze zasadą wzajemności, uważa się, że w ten sposób pomniejszano by czyjeś zasługi w niebie. 
W stosunku do takich elementów w postaci leksykalnej: bodaj, byle, niech, oby, żeby (niespójnikowego) Maciej Grochowski używa terminu operator trybu (1997: 26), Jolanta Antas - operator optatywny (1991: 140). Konkretne analizy wartości semantycznej takich jednostek w zdaniach nie pozostawiają wątpliwości co do ich woluntatywnego i życzeniowego charakteru (dla przykładu: OBY potraktowane jako wykładnik optatiwu realizujący się w definicji 'Oby $P$ : chcąc, żeby stało się $P$, mówię: byłoby dobrze, gdyby stało się to, o czym mówię' (Grochowski 1997: 73). Definicje słownikowe (ISJP i SWJP) pozwalają rozciągnąć te obserwacje na ogólną kategorię znaków wyrażających życzenie, pragnienie, wolę mówiącego, by nastąpił jakiś pożądany stan rzeczy. Operatory tej grupy są w różny sposób wyspecyfikowane semantycznie i pragmatycznie: na przykład niech, $\dot{z} e b y$ - są wolne od sygnalizowania postawy mówiącego wyrażającej lęk, obawę, czy uda się zmiana negatywnego pod jakimś względem stanu rzeczy należącego do presupozycji. Inne taki komponent mogą zawierać (por. Obyśszcześliwie zdał egzaminy: Pres.: 'mam obawę, że możesz nie zdać).

Podstawowy składnik treści wyzwalany w badanych formułach dałoby się eksplikować przez rozwinięcie definicji M. Grochowskiego następująco: niech $P$ 'chcąc, żeby stało się $P$, myśląc, że byłoby dobrze, gdyby stało się to, o czym mówię; mówię: niech się to stanie’. Jak się wydaje, wprowadzenie do definicji składnika performatywnego jest nieodzowne. $\mathrm{W}$ takiej perspektywie badane akty byłyby $\mathrm{z}$ istoty swej zaprzeczeniem złorzeczenia („złego życzenia”), por. Oby ci się poszczęściło za granica, Żeby naszym chłopcom poszło lepiej niż we wczorajszym spotkaniu. Niech ci szczęście sprzyja. Byle nam się jutro udało odpalić auto na tym mrozie. Trudno tu o szersze omówienie tych szczególnych wyrazów funkcyjnych, warto jednak zwrócić uwagę na ich wspólny „życzeniowy” rodowód: bodaj to zleksykalizowane Bóg daj 'niech Bóg da'; niechaj/niech to trzecioosobowa forma rozkaźnikowa dawnego czasownika niechać w znaczeniu 'pozwól, dopuść' (jak scs. $d a<$ daj; ros. nycms 'spuść, zezwól'). By łączące się ze spójnikami jest także odległą kontynuacją trybu życzącego od byti. W czasach wspólnoty pie. - podkreślmy - optativus wyrażał życzenie, które mówiący uważał za możliwe do spełnienia (EJO).

Dla porządku dodajmy, że życzenie można także wyrazić optatywnym użyciem trybu rozkazującego. Z przykładów archaicznych mamy na przykład ciekawe: darz bór!; trzecią osobę reprezentuje Niech się Święci Pierwszy Maja!. Odnajdziemy życzenie w silnie skonwencjonalizowanych formułach typu Boże, prowadź! Boże dopomóż, Boże, daj zdrowie, Boże, chroń króla! itp. Z nowszych: Bądź szczęśliwa w matżeństwie! W gwarze możliwa jest też sytuacja, kiedy zdanie identyfikuje przedmiot życzenia z gramatycznym podmiotem. Takie starodawne formy życzeń - korzeniami sięgające magii sympatycznej (zaklęć), stosowano dawniej w wioskach Kielecczyzny, Pogórza i Podkarpacia, na przykład gdy spożywano wigilijny żur, mierzwiono sobie włosy i mówiono: Wiąż się, żytko, wiq̨ż!, a gdy ziemniaki: Wiążcie się ziemniaczki jak kocie łby!; albo (świadectwo z 2. poł. XIX w.; por. Siarkowski 200o) gdy je posadzono w wigilię św. Marka: Rośnijcie nam pośpiechy, niech doczekamy pociechy - z obowiązkowym przewracaniem się i tarzaniem po zagonie. 
W tworzeniu tekstów życzeń korzystamy zazwyczaj z utrwalonych wzorców tekstowych, w znacznym stopniu zrytualizowanych. Formuliczność życzeń, czasem irytująca pewnym schematyzmem i skostnieniem, ma odległy rodowód. Najłatwiej do niego dotrzeć przez analizę w pewnym sensie prototypowych życzeń spotykanych w zwyczajach ludowych. Niezależnie jednak od tego, czy mają one charakter obrzędowy, religijny czy obiegowy, są rozwinięciem wyjściowych formuł zdaniowych (schematu leksykalno-składniowego) opartych na samodzielnym składniowo operatorze optatywnym (zapewne genetycznie pierwotnym i starszym) lub na użytym performatywnie czasowniku (czasem jest to zdanie rozkazujące). Struktura tekstowa życzeń jest więc oparta na kluczowym elemencie identyfikującym intencję nadawcy. Dowodzą tego opracowania bardziej szczegółowo podejmujące problematykę wzorców tekstowych tego wyjątkowego pod wieloma względami gatunku mowy (por. np. Habrajska 1993, Filip 2007, Sikora 2011).

$\mathrm{Na}$ koniec, jako uzupełnienie przytoczyć można dwa przykłady życzeń nawiązujących do dawnej, obrzędowej tradycji:

\section{Herody - oracja kolędnicza z Odrzykonia}

Dej wom, Boże, pełno wszędzie:

I w kómorze, i na grzędzie.

Żebyście tu mieli dostatku wszelkiego

W chałupie i w stodole.

Żeby się wom zewsząd lały obfitości zdroje:

w każdym kątku po dzieciątku, A na piecu troje.

By się wóm dzieci chowały,

Byście mieli pełno bydła,

By cielęta i źrebięta w oborze skakały,

A krowy po skopcu mleka dawały.

By się wóm pszczoły roiły w pasiekach.

Byście nom tak dobrzy byli, za kolędę zapłacili.

Co nom z serca darujecie, $\mathrm{z}$ laski Boga mieć będziecie,

I na stole, i w stodole - niech wóm Pon Bóg darzy! (Gałązka 2007: 314)

\section{Życzenia dzieci na święto państwowe 3 Maja ${ }^{8}$}

(dla prezydenta Ignacego Mościckiego)

Panie prezydencie! W dniu Twojego święta,

Stoi tu gromadka dzieci uśmiechnięta!

A z tych wszystkich dzieci, każde jedno powie:

niech Ci Bóg da szczęście, niech Ci Bóg da zdrowie!

Niech nad naszym krajem słońce jasno świeci,

I niech dzielni ludzie rosną z polskich dzieci!

8 Zanotowane w czasie badań terenowych w 2003 r. od p. Anny Bilińskiej (ur. w 1928 r.) w Krasnem, w okolicach Sieniawy, w woj. podkarpackim. Wierszyk recytowała z innymi dziećmi podczas szkolnej uroczystości. 


\section{Literatura}

ANTAS J., 1991, O mechanizmach negowania. Wybrane semantyczne i pragmatyczne aspekty negacji, Kraków.

Austin J.L, 1993, Mówienie i poznawanie. Rozprawy i wykłady filozoficzne, Warszawa.

Awdiejew A., 1987, Pragmatyczne podstawy interpretacji wypowiedzi, Kraków.

Awdiejew A., 2007, Gramatyka interakcji werbalnej, Kraków.

BonACCHI S., 2011, Höflichkeitsausdrücke und anthropozentrische Linguistik, Warszawa.

CHudziк A., 2002, Mowne zachowania magiczne w ujęciu pragmatyczno-kognitywnym, Kraków.

EJO: K. Polański (red.), Encyklopedia językoznawstwa ogólnego, Wrocław - Warszawa - Kraków 1993.

Engelking A., 1991a, Magiczna moc słowa w polskiej kulturze ludowej, [w:] J. Anusiewicz, J. Bartmiński (red.), Język a kultura, t. 1: Podstawowe pojęcia i problemy, Wrocław, s. 157-165.

Engelking A., 1991b, Rytuały słowne w kulturze ludowej. Próba klasyfikacji, [w:] J. Bartmiński, R. Grzegorczykowa (red.), Język a kultura, t. 4: Funkcje języka i wypowiedzi, Wrocław, s. $75-85$.

EngelKing A., 2010, Klątwa. Rzecz o ludowej magii słowa, wyd. II, popr., Warszawa.

FILIP G., 2007, Życzenie jako gatunek tekstu, „Stylistyka” t. 16, s. 553-565.

Ga£ązKa B., 2007, Kolędy Podkarpacia. Podgórze I, Krosno.

Grochowski M., 1997, Wyrażenia funkcyjne. Studium leksykograficzne, Kraków.

Habr AJSKa G., 1993, Struktura życzeń świątecznych, „Poradnik Językowy” z. 7, s. 384-396.

ISJP: M. Bańko (red.), Inny słownik języka polskiego, Warszawa 2000.

Kowalski P., 2010, Gratulanci i winszownicy. Zarys komunikacyjnej historii winszowania, Wrocław.

KrawCZyK-Tyrpa A., 1997, Wołanie do Boga (polskie formuly ludowe), [w:] W. Chlebda i A.M. Lewicki (red.), Problemy Frazeologii Europejskiej II, Frazeologia a religia, Warszawa, s. 247-252.

Leech G., 1983, Principles of Pragmatics, London - New York.

Marcjanik M., 1997, Polska grzeczność językowa, Kielce.

MaRCJANiK M., 2007, Grzeczność w komunikacji językowej, Warszawa.

NiebrzEgOWSKA-BARTMIŃsKa S., 2007, Wzorce tekstów ustnych w perspektywie etnolingwistycznej, Lublin.

OżóG K., 1990, Zwroty grzecznościowe współczesnej polszczyzny mówionej (na materiale języka mówionego mieszkańców Krakowa), „Zeszyty Naukowe UJ” CMXIII, „Prace Językoznawcze” z. 98, Warszawa - Kraków.

OżóG K., 2005, Współczesny model polskiej grzeczności językowej, [w:] A. Dąbrowska, A. Nowakowska (red.), Język a Kultura, t. 17: Życzliwość i agresja w języku i kulturze, Wrocław, s. 9-15.

PRZYBYLSKa R., 1986, Co się komu „ciśnie na usta”, czyli o pewnym typie wyrażeń ekspresywnych, „Język Polski” LXVI, z. 5, s. 347-351.

Przybylska R., 2010, Formuły performatywne prowokujace do agresji, [w:] J. Gruchała, H. Kurek (red.), Silva rerum philologicarum. Studia ofiarowane Profesor Marii Strycharskiej-Brzezinie z okazji Jej jubileuszu, Kraków, s. 295-311.

RÉCANATI F., 1987, Meaning and Force: the Pragmatics of Performative Utterances, Cambridge. SEARle J.R., 1987, Czynności mowy. Rozważania z filozofii języka, Warszawa.

SEARLE J.R., 1999, Umysł, język, społeczeństwo, Warszawa. 
SiARKowsKi WŁ. KS., 2000, Materiały do etnografii ludu polskiego z okolic Kielc, cz. 1-3, w oprac. L. Michalskiej-Brachy i K. Brachy, Kielce.

Sikora K., 2011, Winszowanie i dobre słowo w gwarze, „Annales Universitatis Pedagogicae

Cracoviensis”, „Studia Linguistica” VI: Dialog z tradycja, cz. 1., Kraków, s. 171-189.

SWJP: B. Dunaj (red.), Słownik współczesnego języka polskiego, Warszawa 1996.

TomiczeK E., 1992, Z badań nad istota grzeczności językowej, [w:] J. Anusiewicz, M. Marcjanik (red.), Język a kultura, t. 6: Polska etykieta językowa, Wrocław, s. 15-25.

Wierzbicka A., 1973, Akty mowy, [w:] M.R. Mayenowa (red.), Semiotyka i struktura tekstu, Wrocław, s. 201-219.

Wierzbicka A., 1986, Analiza lingwistyczna aktów mowy jako potencjalny klucz do kultury, [w:] A. Brodzka, M. Hopfinger, J. Lalewicz (red.), Problemy wiedzy o kulturze, Wrocław, s. 103-114.

Wierzbicka A., 1987, English Speech Acts Verbs. A Semantic Dictionary, Sydney.

WierzBickA A., 1999, Język - umyst - kultura, Warszawa.

\section{Wishing and congratulating as a speech act Summary}

The paper attempts to synthesize and revise the views on wishing and congratulating as specific speech acts which are represented in Polish by the performative verbs $\dot{z} y c z e, \dot{z} y c z y m y$ 'I/we wish', winszuje, winszujemy 'I/we congratulate', by optative formulas based on aspect operators (niech, oby, aby, żeby 'let', 'so that' \&c.), and sometimes also by imperative sentences. It examines the conditions of fortuitousness of the wishes and their illocutive value, and especially the quite questionable honorific function of wishing formulas, and their connection with the linguistic relics of primitive magical thinking. The proposed interpretations emphasize the cultural and pragmatic function of wishes, rooted in history and tradition. 